\title{
Ultrastructural changes of capillaries of the rat exocrine pancreas at the late burn injury and the application of lyophilized porcine dermal xenograft
}

\author{
Zykova N., Kramar S., Lisnychuk N., Dovgalyuk A., Nebesna Z. \\ Horbachevsky Ternopil National Medical University \\ Corresponding author’s e-mail: zykova@tdmu.edu.ua
}

\section{ABSTRACT}

Deep burns are characterized not only by skin damage, but also cause morphological and functional changes in all organs and systems of the body, which are defined as burn disease. Mediators of inflammatory response and nitroso-oxidative stress in thermal injury adversely affect the internal organs, including the pancreas. Xenografts made from porcine skin by cryopreservation in liquid nitrogen followed by lyophilization and mincing are used to treat burns.

The PURPOSE of the study is to investigate the ultrastructural changes of blood capillaries of the rat exocrine pancreas in the late period after skin burn and under its treatment with lyophilized porcine dermal xenografts.

MATERIALS AND METHODS. 46 adult outbred albino rats were divided into three groups: Group I - intact animals, Group II - rats with seconddegree burn injury, Group III - animals with burn, which underwent necrectomy and the wound was covered with minced lyophilized porcine dermal graft. On the $14^{\text {th }}$ and $21^{\text {st }}$ days, electron microscopic examination of blood capillaries of the exocrine pancreas was performed and the erythrocyte index of intoxication, levels and coefficient of medium molecular weight peptides in the blood were determined.

RESULTS. In Group I, the wall of the capillaries was formed by elongated endothelial cells, which localized on the basement membrane; there were single erythrocytes in the lumen. Endothelial cells contained an elongated nucleus, euchromatin prevailed in the karyoplasm, heterochromatin in the form of small granules had a marginal location. The luminal surface of the endothelium formed outgrowths of the cell membrane, which increased the area of the capillary wall. Pericyte nuclei contained euchromatin.

In Group II, the ultrastructure of blood capillaries was changed - their lumens were enlarged and contained clusters of blood cells. The integrity of capillary wall was disrupted. The nuclei were compacted with a prevalence of heterochromatin, pyknotic, had deep invagination of nucleolemma. The cytoplasm of endothelial cells was light, edematous; organelles are significantly damaged with single pinocytic vesicles. Pericytes contained electron-dense nuclei, their cytoplasm was homogeneous.

In Group III, the structure of the blood capillaries wall was similar to normal. Plasma membranes of endothelial cells were clearly contoured with numerous outgrowths on the luminal surface, the cytoplasm was light, contained pinocytic vesicles and altered organelles. Nuclei of endothelial cells were large, euchromatin prevailed in the karyoplasm. Optically dense pericytes were close to the basement membrane of the capillaries.

According to biochemical studies, burn injury was accompanied by the endotoxemia, as evidenced by increased concentrations of medium molecular weight peptides and increased permeability of erythrocyte membranes.

CONCLUSIONS. In the late period after skin burn, rats develop significant destructive changes in the blood capillaries of the exocrine pancreas, which is manifested by the damage to the components of the nuclei and cytoplasm of endothelial cells. Early necrectomy and the application of porcine dermal xenograft on the $14^{\text {th }}$ and $21^{\text {st }}$ days showed a decrease in the content of toxic catabolites in the blood, which provide the recovery of blood capillary wall structure and normalization of transendothelial metabolism.

KEY WORDS: exocrine pancreas; blood capillaries; burn injury; endotoxemia; porcine lyophilized dermal xenograft 
According to statistics of the World Health Organization, the annual death rate from skin burns is about 180,000 people [1]. Deep burns are characterized not only by the damage to integumentary tissues, but also cause various, prolonged general morphological and functional changes of all organs and systems of the body, which are defined as burn disease [2-6]. Severe burn injury leads to both local and general disorders of the metabolic system, natural resistance to infection and immunological reactivity [7-10].

Thermal exposure to skin causes the destruction and damage of numerous cells with the release of a significant number of various biologically-active compounds - so-called "inflammatory mediators", namely kinins, serotonin, histamine, acute-phase proteins, complement factors, cytokines. They are all vasoactive and able to increase the vascular permeability disrupting the endothelial barrier integrity [11-13]. This contributes to the generalization of the pathologic process and its progression beyond the initial site of injury.

These biological mediators of inflammation and nitroso-oxidative stress, which naturally occur during thermal damage, adversely affect the all internal organs, including the pancreas $[14,15]$. The role of the pancreas as an exocrine and endocrine organ is very important, because the vital functions of the whole organism depend on the integrity of its structure and its functions. Actually, the complexity of the anatomical and physiological parameters of this gland determines its sensitivity to any disorders of homeostasis $[16,17]$.

Modern strategy for the treatment of thermal injuries have led to a reduction in mortality even after massive burns [18-24]. At present, combustiologists use the latest technologies to treat burns using dermal xenografts from porcine skin $[25,26]$. Graft production includes skin cryopreservation in liquid nitrogen, followed by lyophilization and mincing to obtain a substrate of lyophilized dermal xenograft, as well as its derivatives $[27,28]$. Studies of this products have shown that it has a high redox potential, excellent antitoxic and sorption properties, as well as enriched with amino acids and micronutrient elements which generally reduce endotoxemia, and is quite easy to use $[29,30]$.

The PURPOSE of the study is to investigate the ultrastructural changes of blood capillaries of the rat exocrine pancreas in the late period after skin burn and under its treatment with lyophilized porcine dermal xenografts.

\section{MATERIALS AND METHODS}

The study was performed using 46 mature male outbred albino rats weighing $200-250 \mathrm{~g}$, which were kept in the vivarium of I. Ya. Gorbachevsky Ternopil National Medical University. All animal experiments were conducted in compliance with international rules and principles of the "European Convention for the Protection of Vertebrate Animals Used for Experimental and Other Scientific Purposes" (Strasbourg, France, 1986) and the Law of Ukraine \#3447-IV "On Protection of Animals from Cruelty" (dated 21.02.2006).

The object of the study was the pancreas. Rats were divided into $3 \mathrm{ex}-$ perimental groups: Group I - intact animals (12), Group II - animals with burns (16), Group III - animals with burns that underwent necrectomy and the wound was covered with minced lyophilized porcine dermal xenograft (18). Burns were modelled to the epilated skin of the back of animals for 10 seconds under anesthesia with $10 \%$ sodium thiopental $40-50 \mathrm{mg} / \mathrm{kg}$ (Kyivmedpreparat, Ukraine) intraperitoneally. The size of the injured area $\left(24 \mathrm{~cm}^{2}\right)$ was $20 \%$ of the body surface area and classified as seconddegree burn [31]. The burn was modelled with copper plates heated in water at a temperature of $97-100^{\circ} \mathrm{C}$.

One day after the burn, Group III underwent early necrectomy of the injured skin and they were covered with minced lyophilized porcine dermal xenograft produced by "Combustiologist" company (Ternopil, Ukraine). The wound was covered with a sterile bandage treated with Decasan solution (Yuriya-Pharm, Ukraine). Necrectomy was not performed in Group II due to high mortality of animals. Euthanasia of animals in Groups II and III was performed by decapitation under intraperitoneal injection of $10 \%$ sodium thiopental $40-50 \mathrm{mg} / \mathrm{kg}$ (Kyivmedpreparat, Ukraine) on the $14^{\text {th }}$ and $21^{\text {st }}$ days of the experiment, which corresponds to the terms of late toxemia and septicotoxemia of burn disease [32, 33].

For electron microscopy, fragments of the pancreas were fixed in $2.5 \%$ solution of glutaraldehyde (SPI supplies, USA) at pH 7.2-7.4. After fixation, it was washed with phosphate buffer solution for 30 minutes. Post-fixation was performed using $1 \%$ osmium tetroxide solution, followed by dehydration in ethanol of increasing concentration and embedded in a mixture of epoxy resins. For electron microscopic studies, 0.4-0.6 $\mu \mathrm{m}$-thick sections prepared using an ultramicrotome Ultrotome LKB 4801 A (Bromma, Sweden) were contrasted with uranyl acetate and lead citrate according to Reynolds method and examined with an electron microscope PEM-125K (Sumy, Ukraine) [33].

The erythrocyte intoxication index (EII) is one of the markers of endogenous intoxication, which is determined by the amount of $0.025 \%$ methylene blue solution absorbed by the erythrocyte membrane [34]. Another marker of endogenous intoxication is the determination of the content of medium molecular weight peptides (MMWP) in the blood serum, in particular their low molecular weight $\left(\mathrm{MMWP}_{1}\right.$ ) and high molecular weight $\left(\mathrm{MMWP}_{2}\right)$ fractions. This method means isolating the soluble fraction of MMWP followed by measurement of ten-fold diluted supernatant using a spectrophotometer LabAnalyt SP-V1000 (DLAB Scientific Co., LTD, China). The composition of medium molecular weight peptides, which are determined at a wavelength of $254 \mathrm{~nm}\left(\mathrm{MMWP}_{1}\right)$, includes aliphatic amino acids with a molecular weight of up to $5000 \mathrm{Da}$. The composition of medium molecular weight peptides, which are determined at a wavelength of $280 \mathrm{~nm}\left(\mathrm{MMWP}_{2}\right)$, includes aromatic and heterocyclic amino acids, whose molecular weight is 5000-7000 Da. The index of medium molecular weight peptides (MMWPi) was also calculated by the formula: $\mathrm{MMWPi}=\mathrm{MMWP}_{1} / \mathrm{MMWP}_{2}$ [34-37].

Statistical analysis was performed using the MS Excel (Microsoft, USA) and Statistica 6.0 (StatSoft Inc., USA) software. The arithmetic mean (M), the standard error of the mean (SEM) and the standard deviation (б) were calculated for all parameters. The reliability of the difference between the values of the independent samples was determined in the normal distribution by Student's t-test, in other cases - using the MannWhitney U-test. Differences were considered significant at $p<0.05$ [38].

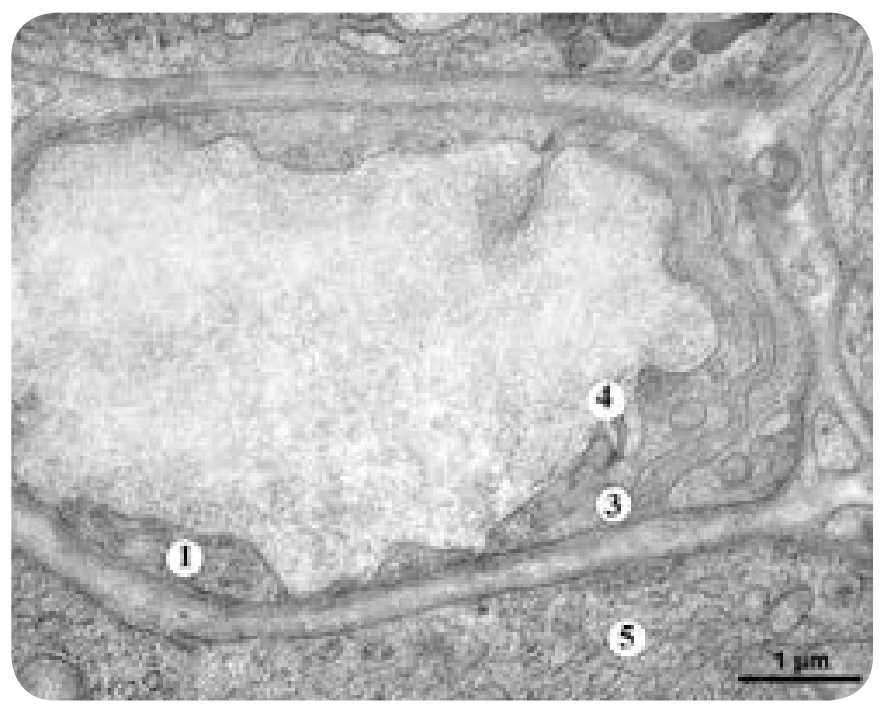

A

Fig. 1. Electron micrograph of the blood capillary of the rat pancreas in the group of intact animals. Electron microscopy Notes: 1 - cytoplasm of endothelial cell; 2 - basement membrane; 3 - intercellular contacts; 4 - cell membrane outgrowths; 5 - acinar cell. 

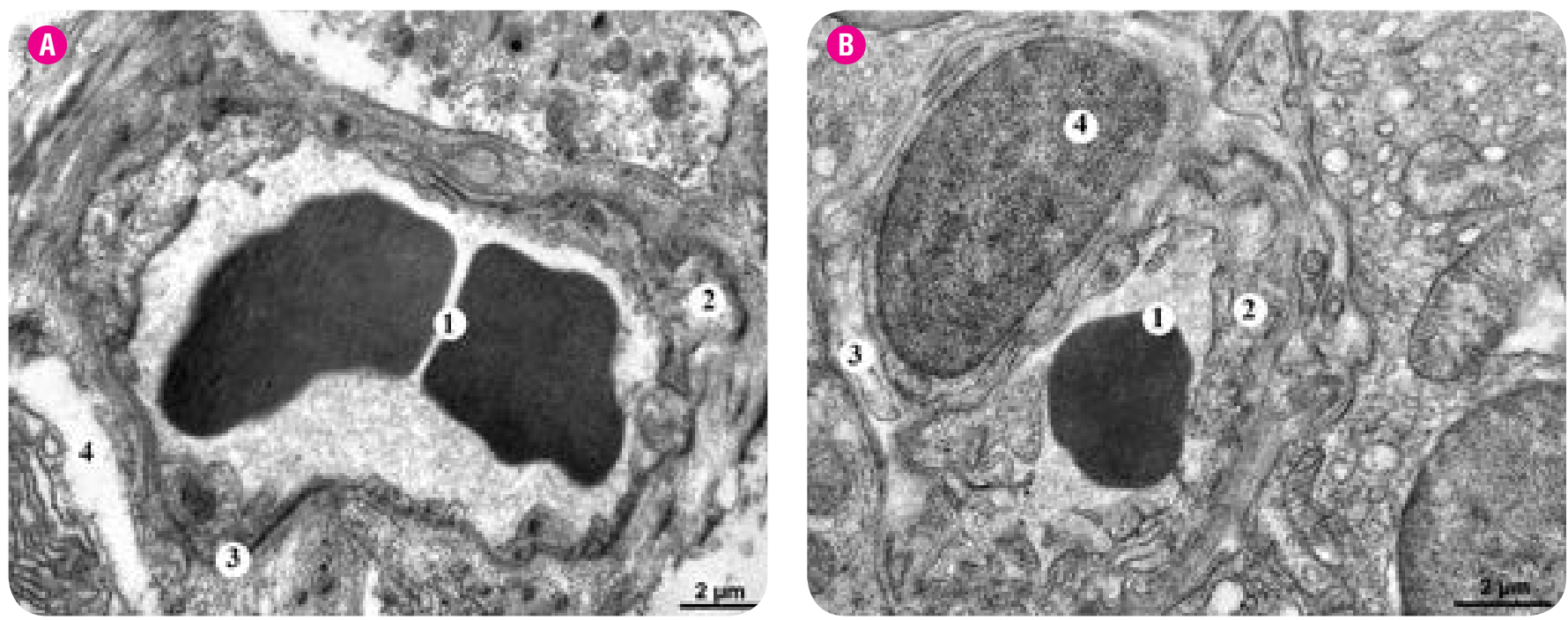

A Fig. 2. Electron micrographs of blood capillaries of the rat pancreas on the $14^{\text {th }}$ day after the experimental thermal injury. Electron microscopy.

A) 1 - capillary lumen with erythrocytes; 2 - destructive changes in endothelial cells; 3 - compacted basement membrane; 4 - perivascular edema

B) 1 - capillary lumen with an erythrocyte; 2 - endothelial cytoplasm; 3 - thickened basement membrane; 4 - pericyte.
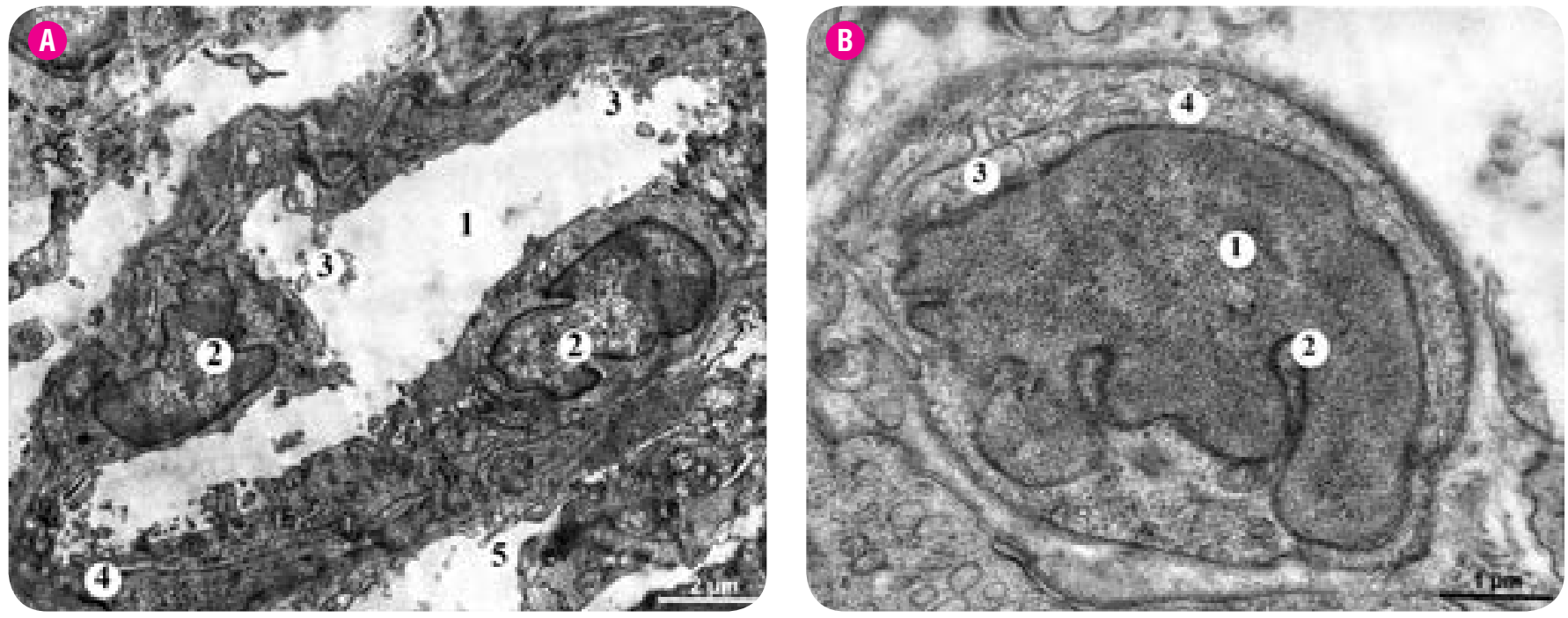

Fig. 3. Electron micrographs of blood capillaries of the rat pancreas on the $21^{\text {st }}$ day after the experimental thermal injury. Electron microscopy. A) 1 - capillary lumen; 2 - irregularly shaped endothelial cell nucleus with invagination of nucleolemma; 3 - cellular detritus in the capillary lumen; 4 basement membrane thickening; 5 - perivascular edema.

B) 1 - nucleus; 2 - invagination of nucleolemma; 3 - mitochondria; 4 - narrow slit-like lumen.

\section{RESULTS AND DISCUSSION}

Electron microscopic studies revealed that in the pancreas of Group 1 the lumens of blood capillaries contained single erythrocytes and leukocytes. The capillary walls were formed by elongated endothelial cells, which localized on the basement membrane. In the cleavage of the basement membrane, or outside it, there were pericytes, whose light cytoplasm contained the endoplasmic reticulum, free ribosomes, the Golgi apparatus, small mitochondria with a moderate matrix density and a few cristae. The nuclei of pericytes are large, containing mainly euchromatin.

The nuclei of endothelial cells were oval in shape with a distinct nucleolus. Euchromatin predominated in the karyoplasm, heterochromatin in the form of small granules had a marginal location. A well-defined nucleolemma with a large number of nuclear pores was determined, and the perinuclear space was not expanded. The cytoplasm contained the main complex of organelles and structural components. Mitochondria are mostly round or oval with a light-dense matrix, surrounded by a solid outer membrane with a few clearly structured cristae. The cytoplasm contained a large number of ribosomes and polysomes, clear tubules of granular endoplasmic reticulum and the Golgi apparatus in the form of elongated cisterns, which periphery included small and large microvesicles with low osmiophilic content. The luminal surface formed outgrowths of plasmalemma, which increase the exchange surface of the capillary wall. Numerous microvesicles and caveolae were observed in cytoplasm (Fig. 1).

Burns cause a complex of various disorders in organs and systems of the body, in particular the digestive system $[4,5]$. The available scientific papers provides very little data on morphological and functional changes in the pancreas at thermal burns of the skin and under its treatment [39], so this area of research is relevant and promising. In 1973, Kemoklidze S. et al. studied the morphofunctional changes of the pancreas in dogs with modeled burns and found that submicroscopic changes in this tissue are primarily manifested by impaired microcirculation. This is one of the 

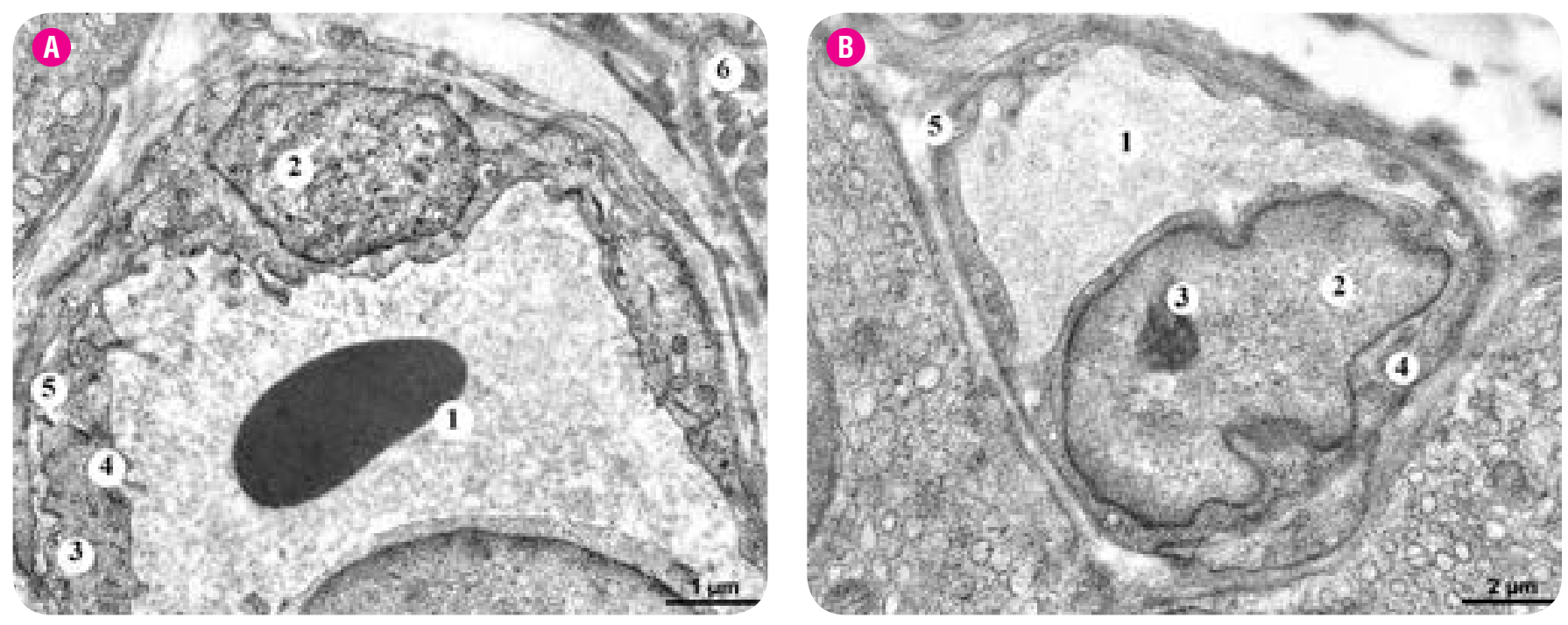

\footnotetext{
Fig. 4. Electron micrographs of blood capillaries of rat pancreas on the $14^{\text {th }}$ day after burn under the treatment with the lyophilized porcine dermal xenograft. Electron microscopy.

A) 1 - capillary lumen with erythrocyte; 2 - endothelial cell nucleus; 3 - endothelial cell cytoplasm; 4 - plasmalemma outgrowths; 5 - thickened basement membrane; 6 - acinar cell.

B) 1 - capillary lumen; 2 - endothelial cell nucleus; 3 - nucleolus; 4 - endothelial cell cytoplasm; 5 - basement membrane.
}

triggers of further changes in the pancreas which are manifested by an involution of parenchymal and growth of stromal components.

Our electron microscopic studies of blood capillaries of the exocrine pancreas of Group II animals are consistent with the results of other researchers and confirm the presence of significant ultrastructural changes in the late periods after burn [15]. Thus, on the $14^{\text {th }}$ day of observation, we found that the lumens of most blood capillaries are enlarged and contain clusters of blood cells. The basement membrane of capillaries was thickened with unsharp contour, and in some areas osmiophilic and homogeneous (Fig. 2 A).

Pericytes contained electron-dense nuclei; their cytoplasm was homogeneous with poorly visualized organelles (Fig. 2 B). The damage to the capillary wall integrity and the destruction of the plasmalemma or intercellular junctions between endothelial cells were observed in some cases, as well as areas of endothelial cells desquamation from the basement membrane.

The nuclei of endothelial cells were partially deformed, elongated, compacted, pyknotic, had deep invagination of nucleolemma with locally expanded perinuclear space. Karyoplasm contained mainly electrondense heterochromatin, disorganized nucleoli were rarely found. However, in some cells the nuclei were enlarged compared with the endothelial nuclei of control experimental animals, and their karyoplasm has light density. The membranes of the nucleolemma had unsharp contour and the expansion of the perinuclear space were detected. The cytoplasm of these cells was light, edematous, and contained significantly damaged organelles. Single pinocytic vesicles were detected. The granular endoplasmic reticulum contained dilated vacuolated tubules with a small number of ribosomes. The cisterns of the Golgi apparatus were fragmented and contained vacuoles with light contents. Mitochondria contained a weakly osmiophilic matrix, their membranes and cristae are indistinct, lysed. Other mitochondria were small with dense damaged matrix and fragmented cristae. Few pinocytic vesicles were found in the cytoplasm, which indicates a lack of transendothelial metabolism (Fig. 2 A).

Serious destructive and degenerative changes of the blood capillary wall were observed on the electron micrographs in Group II on the $21^{\text {st }}$ day of the experiment. Among them there were dilated blood capillaries and capillaries that had narrowed lumens (Fig. 3 A, B). Luminal surfaces were smoothed without a clear border and outgrowths. The basement membrane was thickened, homogeneous, with unsharp contour, com- pacted in most areas, osmiophilic (Fig. 3 B). The disruption of capillary wall integrity with hemorrhage formation and pericyte atrophy was determined in some samples. Endothelial cells with the areas of clearing of the cytoplasm without organelles, as well as the areas with electron-dense cytoplasm and fragmented membranes of the tubules of the endoplasmic reticulum, damaged and destroyed cisterns of the Golgi apparatus were observed. Mitochondria are altered; their cristae are reduced and contain a light matrix. The integrity of the outer membranes of mitochondria was disrupted. Primary and secondary lysosomes were detected. Cytoplasm of the endothelial cells contained single micropinocytic vesicles and caveolae. The nuclei of endothelial cells are compacted, osmiophilic, pyknotic with the predominance of heterochromatin, their nucleolemma had unsharp contour and deep invagination (Fig. $\mathbf{3} \mathbf{A})$. The results of our electron microscopic studies of blood capillaries of the exocrine pancreas correspond to the data of other researchers $[40,41]$.

Electron micrographs in Group III on the $14^{\text {th }}$ day after burns under the application of dermal xenograft as a treatment agent showed better preservation of the blood capillary wall, but there was a slight perivascular edema. Most blood capillaries had moderately dilated lumens without clustering of blood cells, compared with the same term in Group II. Optically dense pericytes were close to the basement membrane of the capillaries. Plasmalemmas of endothelial cells are fuzzy, and luminal surfaces are rough, some areas contained cytoplasmic outgrowths. The basement membrane of blood capillaries was clear, moderately thickened, sometimes homogeneous, electron-dense (Fig. 4 A).

The nuclei of endothelial cells are round-elongated with shallow invaginations of the nucleolemma; perinuclear space was slightly expanded. The karyoplasm contained mainly electron-light chromatin and nucleoli (Fig. 4 B). The cytoplasm had a moderate electron density and contained short and moderately dilated tubules of granular endoplasmic reticulum with a small number of ribosomes, slightly thickened cisterns of the Golgi apparatus with numerous vacuoles. Most mitochondria had an electrondense matrix, clear outer membrane contours, and pronounced cristae, while small mitochondria with the clearing of the matrix and few partially damaged cristae were observed. A large number of pinocytic vesicles and caveolae were found on the periphery of endothelial cells.

On the $21^{\text {st }}$ day after the burn and under the treatment with dermal xenograft, active regenerative processes of the components of the blood capillaries in pancreas were revealed. The capillary wall was thin with 

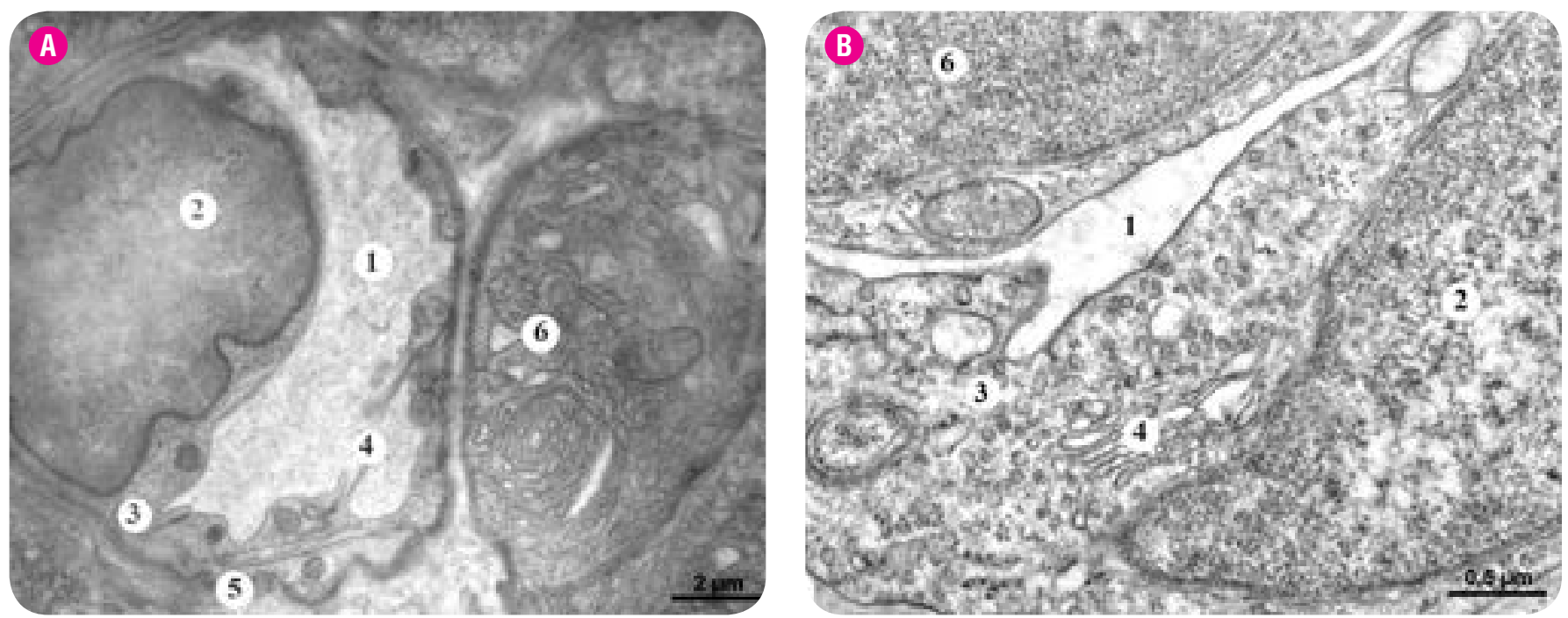

Fig. 5. Electron micrographs of blood capillaries of rat pancreas on the $21^{\text {st }}$ day after burn under the treatment with the lyophilized porcine dermal xenograft. Electron microscopy.

A) 1 - blood capillary lumen; 2 - endothelial cell nucleus; 3 - endothelial cell cytoplasm; 4 -plasmalemma outgrowths; 5 - basement membrane; 6 - acinar cell.

B) 1 - blood capillary lumen; 2 - endothelial cell nucleus; 3 - caveolae and microvesicles in the cytoplasm; 4 - Golgi apparatus cisterns; 5 - basement

membrane; 6 - lymphocyte.

a uniform lumen filled with single normal erythrocytes. Endothelial cells were without pathological changes, their luminal surface contained welldefined outgrowths of plasmalemma, and the integrity of intercellular junctions was preserved (Fig. $\mathbf{5}$ A). The basement membrane was clear; the pericytes were located on the outer side or were in the fissures of the basement membrane and contained a large round or oval nuclei.

There were no perivascular edema around the blood capillaries. A large number of micropinocytic vesicles were observed in the peripheral areas of endothelial cells closer to their luminal surface. Elongated-shape nuclei of endothelial cells were of large size with unexpanded perinuclear space and shallow invagination of nucleolemma. The euchromatin prevailed in the karyoplasm and the presence of large nucleoli was observed. The cytoplasm was light with a large number of free and fixed to the tubules of the endoplasmic reticulum ribosomes, polisomes, as well as distinct Golgi apparatus (Fig. 5 B). Rounded or oval mitochondria with the matrix of moderate osmiophility and a clear outer and inner membrane forming cristae were found. Single, osmiophilic, small lysosomes are rarely observed.

A number of researchers have noted a similar positive effect of minced dermal xenograft on the structural components of the lungs, testes, thyroid gland of animals at the ultrastructural level [42-44].

Under the conditions of modeled thermal trauma, we found the development of endogenous intoxication syndrome. In the dynamics of the experiment there was a marked increase in erythrocyte intoxication index and the content of fractions of medium molecular weight peptides, namely MMWP1 and MMWP2, which are important biological markers of endotoxemia $[45,46]$.

The studies of Ell have shown that in the late periods of burns (the $14^{\text {th }}$ and $21^{\text {st }}$ days) there is a significant increase to $94.1 \pm 2.4 \%$ and 76.5 $\pm 2.2 \%$, which exceeds the intact group of animals 1.73 and 1.41 times $(\mathrm{p}<0.001)$, respectively (Fig. 6).

On the $14^{\text {th }}$ day of the experiment, the content of MMWP1 exceeded that in the group of intact animals and was $0.063 \pm 0.001$ units, which significantly exceeds the level of animals of the intact group 1.26 times $(p<0.001)$, and on the $21^{\text {st }}$ days this parameter was $0.054 \pm 0.001$ units, which significantly exceeds the level of animals of the intact group 1.08 times $(p<0.01)$ (Fig. 7).

A similar change was observed in determining the content of MMWP2. On the $14^{\text {th }}$ day of the experiment, their level exceeded the same para-

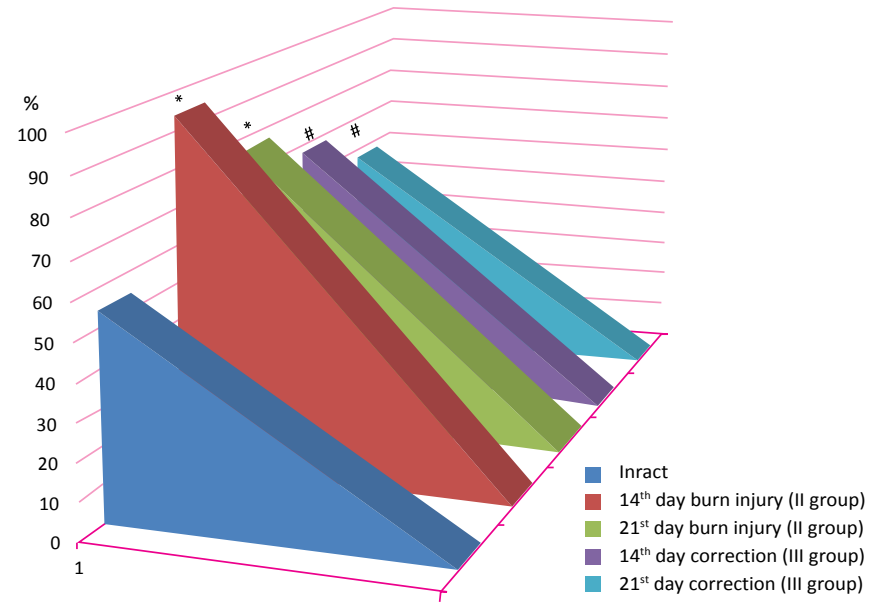

A

Fig. 6. Histograms of erythrocyte intoxication index in rats in the dynamics of burn model and under the treatment with lyophilized porcine dermal xenograft.

Notes: * $-p<0.001$ compared to the group of intact animals; \# $-p<$

0.001 compared to the group of animals with burns.

meter in the group of intact animals 1.44 times and was $0.068 \pm 0.001$ units and on the $21^{\text {st }}$ day -1.17 times and was $0.055 \pm 0.001$ units that differ significantly from the intact group $(p<0.001)$. At the same time, significant changes $(p<0.001)$ of MMWPi were found in all observation periods compared with the intact group of animals (Fig. 8).

The showed changes in the Ell, MMWP1, MMWP2 and MMWPi in Group II indicate the development of endogenous intoxication syndrome, accompanied by functional and morphological lesions of all organs and systems of the body [45-47].

When using the lyophilized dermal xenograft, a decrease in the level of endotoxemia markers was observed (Fig. 6). On the $14^{\text {th }}$ day, the Ell was significantly lower $(p<0.001)$ than that of animals with burn without treatment and was $67.6 \pm 2.0 \%$, but still significantly 1.25 times higher than that of animals in the intact group $(p<0.001)$. On the $21^{\text {st }}$ day, this index was significantly lower $(p<0.001)$ than in animals with burns without treatment and was $57.2 \pm 1.2 \%$, which did not differ from that in animals of the intact group. 


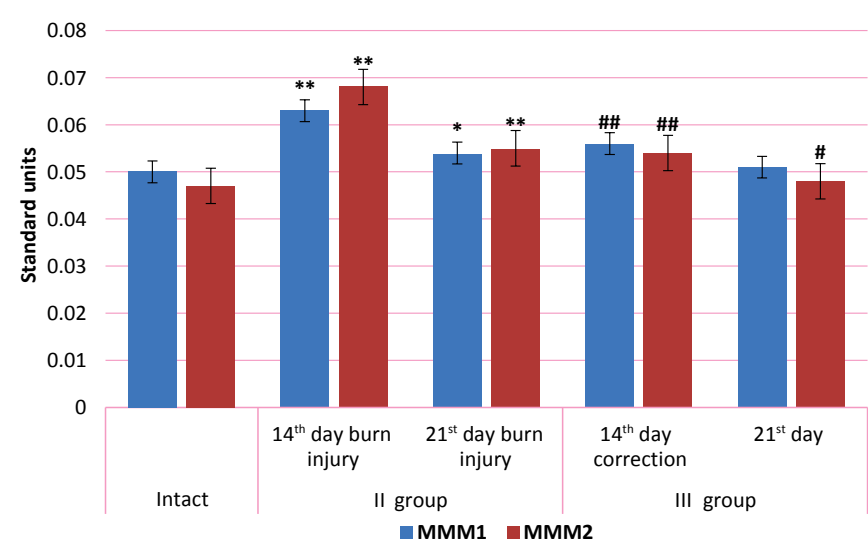

Fig. 7. Comparative characteristics of MMWP1 and MMWP2 content in rats in the dynamics of burn model and under the treatment with lyophilized porcine dermal xenograft. Notes:

${ }^{*}-p<0.01,{ }^{* *}-p<0.001$ compared to the group of intact animals,

$\#-p<0.01$,\# $-p<0.001$ compared to the group of animals with burns.

The level of MMWP1 on the $14^{\text {th }}$ day was $0.056 \pm 0.001$ units, which is significantly lower $(p<0.001)$ than that of the control group animals, but still significantly 1.12 times higher than the level of the intact group animals $(p<0.01)$. On the $21^{\text {st }}$ day, the content of MMWP1 in blood serum was $0.051 \pm 0.002$ units and is similar to that of intact animals (Fig. 7).

On the $14^{\text {th }}$ day under the treatment, the level of MMWP2 decreased in comparison with animals with burns and was $0.054 \pm 0.001$ units $(p<0.001)$. On the $21^{\text {st }}$ day, this level was $0.048 \pm 0.002$ units, and was significantly lower $(p<0.01)$ compared with the same parameter in the group of animals with burns without treatment (Fig. 7).

The MMWPi on the $14^{\text {th }}$ and $21^{\text {st }}$ days after the treatment were significantly decreased $(p<0.001)$ compared with the group of animals without treatment and amounted to $0.96 \pm 0.02$ and $0.94 \pm 0.02$ units, respectively (Fig. 8).

Analyzing the dynamics of changes in endotoxemia markers in the treatment of burns, a positive effect of the use of lyophilized porcine dermal xenograft was determined. Thus, a significant decrease in all studied

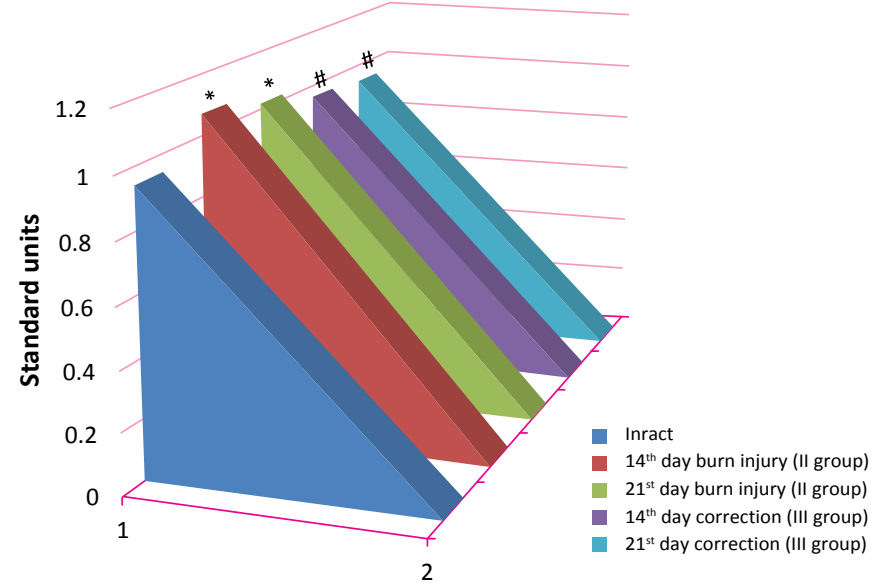

A

Fig. 8. Diagrams of MMWPi content in rats in the dynamics of burn model and under the treatment with lyophilized porcine dermal xenograft. Notes: * $-p<0.001$ compared to the group of intact animals: $\#-p<0.001$ compared to the group of animals with burns.

parameters on both the $14^{\text {th }}$ and $21^{\text {st }}$ days of observation was revealed. Similar results on the pronounced positive effect of using dermal xenograft to reduce the manifestations of endotoxemia and septicotoxemia in the experiment are reported in the other studies [29].

Thus, in the late periods after skin burn, significant destructive changes in the walls of blood capillaries of the exocrine pancreas develop. These disorders are manifested by the disruption of the components of the nuclei and cytoplasm of endothelial cells, which adversely affects the functional state of the body in general. In Group III, when performing early necrectomy of the affected tissue with the use of minced dermal xenograft substrate on the $14^{\text {th }}$ and, especially, on the $21^{\text {st }}$ day, there was a decrease in the severity of endo- and septicotoxemia. This provides the necessary conditions for the restoration of structural components of the blood capillary wall of the exocrine pancreas. In particular, there was a decrease in the degree of damage of organelles and cytoplasm of endothelial cells, restoration of their nuclei, increase in the number of pinocytic vesicles and outgrowth on the luminal surfaces of these cells, which normalized transendothelial transport in the tissue.

\section{CONCLUSION}

Therefore, on the results of ultrastructural and biochemical studies of the microcirculatory bed of the exocrine pancreas at thermal trauma and under treatment with porcine dermal xenograft, a pronounced positive effect of tissue therapy on blood capillary was showed.

In the treatment of burns with porcine dermal grafts, there was determined the preservation of the integrity of intercellular junctions and the structure of the basement membrane of pancreatic capillaries clearly defined outgrowths of the luminal surface of endothelial cells, the presence of a large number of micropinocytic vesicles in their cytoplasm and caveolae, normalization of endothelial and pericyte nuclei with a predominance of active euchromatin in the karyoplasm, no invagination of the nucleolemma and perinuclear space expansions.

The applied xenograft significantly reduced the manifestations of endo- and septicotoxemia, which can help restore the functional capacity of blood capillaries and normalize transendothelial transport.

\section{REFERENCES:}

1. Burns. World Health Organization. Available from: https://www.who.int/news-room/fact-sheets/detail/burns

2. Klimenko MO, Netyukhailo LG. Burn disease (pathogenesis and treatment). Poltava, 2009. 118 p. [in Ukrainian]

3. Kozinets GP, et al. Clinical efficacy of Lactoprotein with sorbitol in patients with deep and widespread burns. Clinical surgery. 2008; (9):31-33. [in Ukrainian]

4. Netyukhailo LG, Kharchenko SV, Kostenko AG. Pathogenesis of burn disease (part 1). The world of medicine and biology. 2011; 1:127-31. [in Ukrainian]

5. Netyukhailo LG, Kharchenko SV, Kostenko AG. Pathogenesis of burn disease (part 2). The world of medicine and biology. 2011; 1:131-35. [in Ukrainian] 
6. Demling RH. Burns: what are the pharmacological treatment options. Crit Care Med. 2008; 9:1895-1908.

7. Boyarskaya GM, Osadcha Ol, Kozynets GP. Investigation of immunological reactivity of the organism in case of burn injury. Physiol J. 2000; 46(6):68-74. [in Ukrainian]

8. Klimenko MO, Netyukhailo LG. Pathobiochemistry of metabolism. Poltava, 2012. 37 p. [In Ukrainian].

9. Shupp J, Nasabzadeh T, Posenthal D, et al. A review of the local pathophysiologic bases of burn wound progression. J Burn Care Res. 2010; 31(6):849-873.

10. Kao CC, Garner WL. Acute burns. Plast Reconstr Surg. 2000; 105:2482-2492.

11. Adly A. Oxidative stress and disease: an updated review. Res J Immunol. 2010; 3 (2):129-14.

12. Cakir B, Cevik H, Contuk G. Leptin ameliorates burn-induced multiple organ damage and modulates postburn immune response in rats. Regul Pept. 2005; 25(1-3):135-144.

13. Lachiewicz AM, Hauck CG, Weber DJ, Cairns BA, van Duin D. Bacterial Infections After Burn Injuries: Impact of Multidrug Resistance. Clin Infect Dis. 2017; 65(12):2130-2136. DOI: 10.1093/cid/cix682. PMID: 29194526

14. Zykova NP. Microscopic changes of the pancreas vessels in the dynamics after experimental thermal injury. Biomedical and Biosocial Anthropology. 2021; (42):23-28. DOI: 10.31393/bba42-2021-04

15. Kemoklidze SA. Morphofunctional changes in the pancreas in burn disease. Tbilisi, 1973. 55 p. [in Russian]

16. Daamen L, Smits F, Besselink M, Busch O, Rinkes I, Santvoort H, et al. A web-based overview, systematic review and meta-analysis of pancreatic anastomosis techniques following pancreatoduodenectomy. Pancreas. 2021; DOI: 10.1007/978-90-368-2518-4_14

17. Yuan Qionglan, Pan Aihua, Fu, Yuanshan, Dai Yalei. Anatomy and physiology of the pancreas. 2021. DOI: 10.1016/B978-0-12-819402-7.00001-2

18. Maden M. Optimal skin regeneration after full thickness thermal burn injury in the spiny mouse. Acomys cahirinus. Burns. 2018; 44(6):1509-1520. DOI: 10.1016/j. burns.2018.05.018

19. Carta T, Gawaziuk JP, Diaz-Abele J, Liu S, Jeschke M, Logsetty S. Properties of an ideal burn dressing: A survey of burn survivors and front-line burn healthcare providers. Burns. 2019; 45(2):364-368. DOI: 10.1016/j.burns.2018.09.021

20. Chouhan D, Dey N, Bhardwaj N, Mandal BB. Emerging and innovative approaches for wound healing and skin regeneration: Current status and advances. Biomaterials. 2019; 216:119267. DOI: 10.1016/j.biomaterials.2019.119267

21. Greenhalgh DG. Management of Burns. New England Journal of Medicine. 2019; 380(24):2349-2359. DOI:10.1056/nejmra1807442

22. Luze H, Nischwitz S, Kamolz L-P. The use of antiseptics in burn wounds - Our perspective. Burns. 2020; 46(4): 980-981. D0l: https://doi.org/10.1016/j. burns.2020.03.021

23. Momeni M, Fallah N, Bajouri A, Bagheri T, Orouji Z, Pahlevanpour $P$, et al. A randomized, double-blind, phase I clinical trial of fetal cell-based skin substitutes on healing of donor sites in burn patients. Burns. 2019; 45(4):914-922. D0l: 10.1016/j.burns.2018.10.016.

24. Jiang YN, Wang $Y X$, Zheng YJ, Hu XY, He F, Shi WJ, et al. Clinical study of cell sheets containing allogeneic keratinocytes and fibroblasts for the treatment of partial-thickness burn wounds. Zhonghua Shao Shang Za Zhi. 2020; 36(3):171-178. DOI: 10.3760/cma.j.cn501120-20191113-00426

25. Takayuki Y, Hayato I, Timothy W, King H, Hara D, Cooper K. Skin xenotransplantation: Historical review and clinical potential. Burns. 2018; 44(8):1738-49.

26. Huda NV, Tsimbaliuk AV. The content of amino acids and microelements in cryolyophilized xenoskin as an indicator of their biological activity. Medical chemistry. 2012; 14(1/50):70-72. [in Ukrainian]

27. Pavliuk B, Stechyshyn I, Kramar S, Chubka M, Hroshovyi T. Therapeutic efficacy of the developed gel «Xeliogel» on a burn wound model in rats. Pol Merkur Lekarski. 2020; 48(287):331-334. PMID: 33130793.

28. Pavliuk B, Stechyshyn I, Kramar S, Chubka M, Hroshovyi T. The effect of gel "Xeliogel" at the stages of the regeneration of aseptic burn wound in the experiment. Pol Merkur Lekarski. 2021; 49(293):352-355.

29. Klisch IM, Tsymbaliuk AV. The state of endogenous intoxication and indices of nonspecific immune defense of the body during the local use of a crushed Iyophilized xenodermoimplant substrate for the closure of infected burn wounds of III-IV degrees in the experiment. Medical chemistry. 2013; 15(1): 53-57. [in Ukrainian]

30. Vons B. V., Chubka M. B., Groshovyi T. A. The problem of treatment of burns' wounds and characteristic of drugs for the local treatment of burns. Current issues in pharmacy and medicine: science and practice 2018; 11(1):119-125. [in Ukrainian]

31. Regulations on the system of combustiological care in Ukraine. Ministry of Health of Ukraine, order \#838 from 30.09.2013. Available from: https://zakon.rada.gov. ua/laws/show/z2026-13\#Text [in Ukrainian]

32. Kozhemyakin YuM, Chromov OS, Filonenko MA, et al. Scientific and practical recommendations for the for the care and use of laboratory animals. Kiev: Interservis. 2017. 182 p. [in Ukrainian]

33. Horalskyi LP, Khomych VT, Kononskyi OI. Fundamentals of histological technique and morphofunctionalmethods of research in normal and pathology. Zhytomyr: ZhNAEU. 2019. 286 p. [in Ukrainian]

34. Togaybaev AA, Kurguzkin AV, Rikun IV, Karibzhanova RM. A method for the diagnosis of endogenous intoxication. Laboratory work. 1988; 9:22-24. [in Russian]

35. Vlizlo VV, Fedoruk RS, Ratych IB. Laboratory research methods in biology, animal husbandry and veterinary medicine: handbook. Lviv, 2012. 764 p. [in Ukrainian]

36. Andriychuk /Ya, Soroka SE. The effect of induced carcinogenesis on biological markers of endotoxemia. Biology wa tibbiyot muammolari. 2017; 2,1 (95):399-400. [in Russian]

37. Yavorska Sl. Lisnychuk NYe, Andriichuk IYa, Soroka YuV, Stravska MYa. Influence of induced carcinogenesis on biological markers of endotoxemia. World of Medicine and Biology. 2018; 1(63):137-140.

38. Avtandilov GG. Medical morphometry. Moscow: Medicine. 1990. 384 p. [in Russian]

39. Zikova NP, Nebesna ZM, Kramar SB, Litvinyuk SO. Influence of exogenous and endogenous factors on the morphology of the pancreas (literature review). Bulletin of Medical and Biological Research. 2020; (4):143-149. DOl: 10.11603/bmbr.2706-6290.2020.4.11828. [in Ukrainian]

40. Zinenko $D Y u$, Tverdokhlib IV. Ultrastructural characteristics of the hemomicrocirculatory bed and parenchymatous-stromal elements of the pancreas and liver in a model of acute pancreatitis using different doses of sodium taurocholate. Morphologia. 2020; 14(1):23-34. DOl: 10.26641/1997-9665.2020.1.23-34. [in Ukrainian]

41. Quesada R, Simon C, Radosevic A, Poves I, Grande L, Burdio F. Morphological changes of the pancreas after pancreaticoduodenectomy. Scientific Reports. 2019; 9(1):14517. DOI: $10.1038 / \mathrm{s} 41598-019-51173-1$

42. Nebesna ZM, Volkov KS. Structural and morphometric reorganization of pulmonary vessels after experimental thermal trauma and under conditions of lyophilized xenoskin substrate application. Bulletin of morphology. 2015; 21(2):348-352. [in Ukrainian]

43. Mukha SYu. Histological and morphometric changes of rat testicles after experimental thermal trauma and under the use of xenodermal substrate. Clinical anatomy and operative surgery 2019; 18(4(70)):17-23. [in Ukrainian] 
44. Koritskiy VG, Nebesna ZM, Lykhatsky PG. Ultrastructural changes of the thyroid gland in the dynamics after experimental thermal trauma under the conditions of application of crushed substrate of lyophilized xenoskin. Clinical anatomy and operative surgery. 2018; 17(4):30-5. [in Ukrainian]

45. Matveev SB, Smirnov SV, Tazina EV, Shakhlamov MV, Godkov MA, Borisov VS. The dynamics of endogenic intoxication in patients with extensive burns. Klin Lab Diagn. 2013; 2:10-2. [in Russian]

46. Krynytska I, Marushchak M, Svan O, Akimova V, Mazur L, Habor H. The indices of endogenous intoxication in rats with carrageenan solution consumption. Georgian Med News. 2018; 279:196-200.

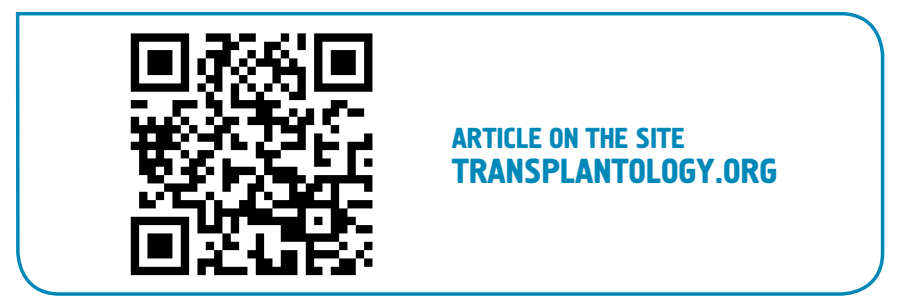

The authors declared no potential conflicts of interest with respect to the research, authorship, and/or publication of this article. 


\section{Ультраструктурні зміни гемокапілярів екзокринної частини підшлункової залози у щурів у пізні терміни після експериментальної термічної травми шкіри та при застосуванні ліофілізованих ксенотрансплантатів шкіри свині}

Зикова Н. П., Крамар С. Б., Лісничук Н. Є., Довгалюк А. І., Небесна 3. М.

Тернопільський національний медичний університет імені І. Я. Горбачевського МОЗ України, Тернопіль, Україна

\section{АНОТАЦІя}

Глибокі поширені опіки характеризуються не лише пошкодженням покривних тканин, а й викликають морфологічні та фуункціональні зміни всіх органів і систем організму, які об'єднуються нозологічним поняттям «опікова хвороба». Біологічні медіатори запальної реакції та нітрозо-оксидативного стресу при термічному ураженні негативно впливають на стан внутрішніх органів, зокрема підшлункової залози. Для корекції опіків застосовують ксенотрансплантати, виготовлені на основі шкіри свині шляхом кріоконсервування у рідкому азоті з наступною ліофілізацією та подрібненням.

META РОБОтИ - дослідити ультраструктурні зміни гемокапілярів екзокринної частини підшлункової залози щурів у пізні строки після опікової травми шкіри та за умов їі корекції ліофілізованими трансплантатами.

МАTEPІАЛИ I МЕТОДИ. 46 статевозрілих аутбредних щурів було поділено на три групи: I - інтактні тварини, II - 3 опіковою травмою ІІб ступеня, III - тварини з опіковою травмою, яким проводили некректомію та покривали рану подрібненим субстратом ліофрілізованої шкіри свині. На 14-у та 21-у добу проводили електронномікроскопічне дослідження гемокапілярів підшлункової залози та визначали еритроцитарний індекс інтоксикації, рівні та коефріцієнт середньомолекулярних пептидів в сироватці крові.

РЕЗУЛЬТАТИ. У I групі тварин у просвіті кровоносних капілярів спостерігались поодинокі еритроцити. Стінка кровоносних капілярів була утворена ендотеліоцитами витягнутої форми, які лежали на базальній мембрані. Ендотеліоцити містили витягнуті ядра, в каріоплазмі яких переважав еухроматин, а гетерохроматин у вигляді невеликих грудок мав маргінальне розміщення. Люмінальна поверхня ендотелію утворювала вирости цитоплазматичної мембрани, які збільшували обмінну поверхню капілярної стінки. В ядрах перицитів чітко візуалізувався еухроматин.

У II групі змінювалась ультраструктура гемокапілярів - їх просвіти розширені та містили клітини крові. Спостерігалось пошкодження стінки капілярів. Ядра ендотеліоцитів були ущільнені з переважанням гетерохроматину, пікнотичні, мали глибокі інвагінації каріолеми. Цитоплазма ендотеліоцитів просвітлена, набрякла, зі значно пошкодженими органелами та поодинокими піноцитозними везикулами. Перицити містили електроннощільні ядра, їх цитоплазма була гомогенною.

У III групі тварин стан стінки гемокапілярів був близький до норми. Мембрани плазмолем ендотеліоцитів чітко контуровані з численними виростами на люменальній поверхні, цитоплазма дещо просвітлена, містила піноцитозні везикули та незмінені органели. Ядра ендотеліоцитів великих розмірів, в каріоплазмі переважав еухроматин. Оптично щільні перицити тісно прилягали до базальної мембрани капілярів.

За даними біохімічних досліджень опікова травма супроводжувалась розвитком синдрому ендотоксемії, про що свідчило зростання концентрацій середньомолекулярних пептидів та підвищення проникності еритроцитарних мембран.

ВИСНОВки. У пізні строки після опікової травми шкіри у щурів розвиваються значні деструктивні зміни гемокапілярів екзокринної частини підшлункової залози, що проявляється пошкодженням компонентів ядер та цитоплазми ендотеліоцитів. При проведенні ранньої некректомії та застосуванні подрібненого субстрату шкіри свині на 14 та 21 добу встановлено зниження вмісту токсичних катаболітів у крові, що створює необхідні умови для відновлення компонентів стінки гемокапілярів і нормалізації трансендотеліального обміну.

КЛЮчОВІ СлОВА: підшлункова залоза; гемокапіляри; опікова травма; ендотоксемія; ліосрілізований ксенотрансплантат шкіри свині 